\title{
The first fossil record of a giant horsetail (Equisetum, Equisetaceae) is from the Miocene of Patagonia, Argentina
}

\author{
*Maria C. Zamaloa ${ }^{1}$, Elina Cornou ${ }^{2}$, Marcelo Martínez², Mirta Quattrocchio ${ }^{3}$, \\ Daniela Olivera ${ }^{2}$, Carlos Zavala ${ }^{3}$, Marcos Asensio $^{4}$
}

\author{
${ }^{1}$ Museo Paleontológico Egidio Feruglio, Avda. Fontana 140, 9100 Trelew, Chubut, Argentina. \\ mzamaloa@gmail.com \\ 2 Instituto Geológico del Sur, Departamento de Geología, Universidad Nacional del Sur, Consejo Nacional de Investigaciones Cientificas \\ y Técnicas, Avda. Alem 1253, Cuerpo B, 8000 Bahía Blanca, Buenos Aires, Argentina. \\ elina.cornou@uns.edu.ar;martinez@criba.edu.ar; daniela.olivera@uns.edu.ar \\ 3 Departamento de Geología, Universidad Nacional del Sur, Avda. Alem 1253, Cuerpo B, 8000 Bahía Blanca, Buenos Aires, Argentina. \\ mquattro@criba.edu.ar; czavala@gcsargentina.com \\ 4 Yacimientos Petroliferos Fiscales Sociedad Anónima, Boulevard Macacha Güemes 515, 1106 Ciudad Autónoma de Buenos Aires, Argentina. \\ marcos.a.asensio@ypf.com
}

* Corresponding author: mzamaloa@gmail.com

\begin{abstract}
A Miocene macroflora recovered from Ñirihuau Formation sediments exposed at Quebrada Vera site in northwesterern Patagonia, Argentina, is recorded and described for the first time. The assemblage is composed exclusively of free-sporing plants, mainly by Equisetum remains with subordinate occurrences of four fern morphotypes (represented by bi-, tri- and pinnate fronds). Equisetum imprints and molds include distinctive jointed stems with whorls of linear and basally fused leaves, numerous scars of lateral branches arranged in a radially symmetrical pattern situated at the nodes, and nodal diaphragms of up to $4 \mathrm{~cm}$ in diameter. The large size and regular branching of the stems link the fossils to the South American giant members of the genus and they probably represent a new fossil species. This is the first conclusive fossil record of a giant Equisetum worldwide, and consequently, it is biogeographically and evolutionarily relevant. The new findings attest that members of the giant horsetail clade were components of the Patagonian vegetation in the Miocene, implying that the age of the clade must predate that estimated from morphological and/or molecular data. The plant fossil assemblage represents part of a wetland community probably growing close to a riverside or lakeshore in coincidence with previous sedimentological estimates.
\end{abstract}

Keywords: Equisetales, Ferns, Pteridophyta, Miocene, Nirihuau Formation, Paleoflora, Paleoenvironment.

RESUMEN. El primer hallazgo de un equiseto gigante fósil (Equisetum, Equisetaceae) proviene del Mioceno de la Patagonia Argentina. Se estudia y describe una macroflora del Mioceno recuperada de los sedimentos de la Formación Ñirihuau aflorantes en el sitio Quebrada Vera, en el noroeste de Patagonia, Argentina. La asociación florística está compuesta exclusivamente por helechos entre los que domina Equisetum acompañado por cuatro morfotipos de frondes de helechos. Los restos fósiles de Equisetum incluyen improntas y moldes de tallos carenados con verticilos de hojas reducidas; nudos con múltiples cicatrices de ramas laterales dispuestas radialmente y diafragmas nodales de hasta $4 \mathrm{~cm}$ de diámetro. El gran diámetro de los tallos y el patrón regular de las ramificaciones vinculan a los fósiles con las especies sudamericanas de Equisetum de gran porte. Este es el primer registro fósil fehaciente a nivel mundial de un Equisetum gigante y, en consecuencia, reviste relevancia biogeográfica y evolutiva. Estos hallazgos, que probablemente pertenezcan a una nueva especie, demuestran que los grandes equisetos eran parte de la vegetación patagónica en el Mioceno, y más antiguos de lo estimado por previos estudios filogenéticos morfológicos y/o moleculares. La asociación florística estudiada representa parte de una comunidad de paleohumedal que probablemente se desarrollaba en la ribera de un río o un lago, paleoambiente similar al propuesto previamente para el área en base a estudios sedimentológicos. 


\section{Introduction}

A Miocene megaflora recovered from outcrops of the Nirihuau Formation exposed at Quebrada Vera site, northwest Patagonia, Argentina, is reported and described for the first time. The plant assemblage consists entirely of pteridophyte remains and it is heavily dominated by the horsetail Equisetum L.

Representatives of the genus Equisetum are the only living members of the once abundant, diverse, and worldwide distributed group of vascular plants, the Equisetales. These ancient and morphologically distinctive free-sporing plants have a long geologic history that can be traced from the Devonian to the recent (Taylor et al., 2009). Living Equisetum species, commonly known as horsetails, grow naturally throughout much of the world; although they are absent in Australia, New Zealand, Antarctica, and islands of the Central Pacific, Indian, and South Atlantic oceans (Schaffner, 1930). Most of the 18 living species are distributed in the Northern Hemisphere and four species grow naturally in South America (Christenhusz et al., 2019).

Regarding the fossil record, the genus Equisetites Sternberg, established for specimens preserved as casts, impressions, and compressions having similar gross morphological characters with the extant genus Equisetum, was frequently chosen by researchers to accommodate Paleozoic and Mesozoic material while Cenozoic horsetails are usually placed in the genus Equisetum (Rozefelds et al., 2019). This criterion is followed in the present contribution.

Systematic studies of Cenozoic Equisetum and related forms (i.e., Equisetites) in the Southern Hemisphere are remarkably limited. Recent findings of vegetative remains with horsetail morphology were reported in the late Eocene or Oligocene (Rozefelds et al., 2019) and in the middle Miocene (Holmes and Anderson, 2019) of Australia, and in the middle Miocene of New Zealand (Pole and McLoughlin, 2017). These records, although scarce, indicate that Equisetum was present in the Australian-New Zealand floras at least until the early Neogene period.

Particularly in South America, the Mesozoic records are represented by about thirteen species of Equisetites found at several Argentine localities (Falaschi et al., 2009, fig. 3) and by two species of Equisetum from Argentine Patagonia (Channing et al., 2011; Elgorriaga et al., 2015); whereas in the Cenozoic the equisetalean occurrences are represented by small stem impressions and molds from the Late Miocene, Pliocene, and Holocene of northern Argentina (Anzótegui and Horn, 2011; Contreras and Lutz, 2014; Robledo et al., 2020).

Equisetum records in South America during most of the Cenozoic are notoriously scarce. Hence, the question that arises is whether its absence in the paleofloras (or in their corresponding collections) is reflecting an effective lack of the plants in the past communities, probably linked to the horsetails growth habit as social plants (sensu Spatz et al., 1998) in almost monospecific stands, or alternatively, if it is the consequence of an insufficient, incomplete and/ or biased sampling of the fossil sites.

The aims of this contribution are 1) to report the first record of a flora recovered from the Miocene Nirihuau Formation at the Quebrada Vera site; 2) to present a detailed morphologic study of the plant fossil assemblage focusing on the Equisetum species that dominates the association, and 3) to assess the potential relevance of this new record in a phylogenetic, paleobiogeographic and paleoenvironmental context.

\section{Geological setting, age and paleoflora}

The fossil material comes from Quebrada Vera site (ca. $\left.41^{\circ} 26^{\prime} \mathrm{S}-71^{\circ} 08^{\prime} \mathrm{W}\right)$ located at the Cordón Las Bayas hills, about $30 \mathrm{~km}$ south of the San Carlos de Bariloche City, W Río Negro Province, Argentina (Fig. 1).

Stratigraphically, the fossiliferous horizons exposed at this locality belong to the Nirihuau Formation (González Bonorino and González Bonorino, 1978) and were deposited in the northern sector of the homonymous basin (Bechis et al., 2014 and references therein). The Nirihuau Basin is located at the eastern flank of the North Patagonian Andes, west-central Argentina (Fig. 1A), and extends approximately $200 \mathrm{~km}$ in a north-south direction between $41^{\circ}$ and $43^{\circ} \mathrm{S}$. The basin infill in the northern depocenter is represented, from base to top, by the Ventana, Nirihuau, and Collón Curá formations (e.g., González Bonorino and González Bonorino, 1978; Cazau et al., 1989; Bechis et al., 2014).

The Nirihuau Formation is a lithostratigraphic unit comprising clastic and pyroclastic sedimentary rocks, with scarce participation of carbonates (e.g., Cazau, 1972; Cazau et al., 1989; Spalletti, 1981; 


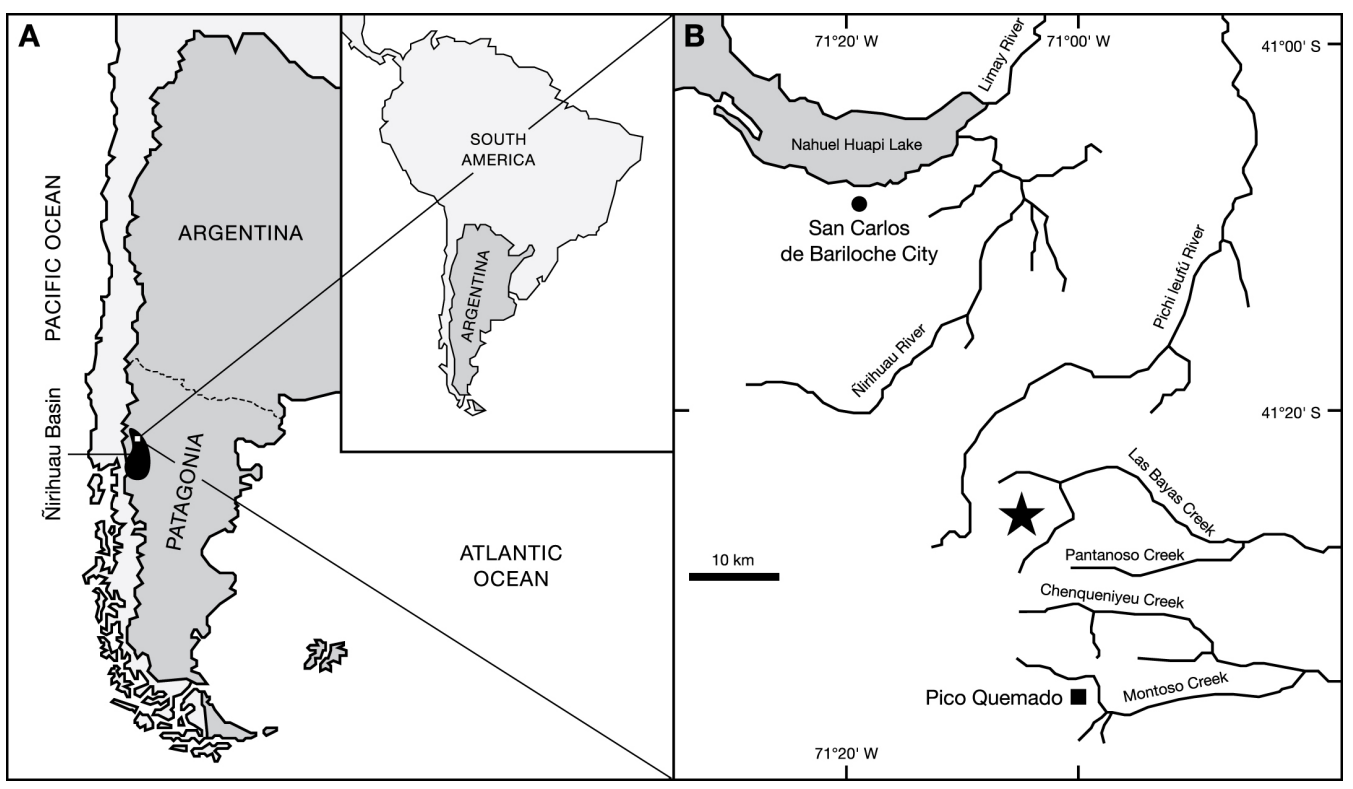

FIG. 1. A. Map showing the Ñirihuau Basin location in Northwest Patagonia, Argentina. B. Map showing the Quebrada Vera site location (star).

Paredes et al., 2009), that are interpreted as deposited in fluvial and lacustrine environments (Santonja et al., 2021 and references therein). The material herein studied comes from the sedimentary lower member of this unit.

The onset of the deposition of the Nirihuau Formation is controversial. Among other authors, Asensio et al. (2010, fig. 2), proposed a latest Oligocene to early Miocene span, while more recent studies (e.g., Bechis et al., 2014; Santonja et al., 2021) constrain the whole Nirihuau Formation deposition to the Miocene.

Paleofloristic records from exposures of the lower member of this formation are only known from the Pico Quemado locality that is separated approximately $5 \mathrm{~km}$ south from the Quebrada Vera site. Paleofloristic reports include a Proteaceae leaf (Frenguelli, 1943), Polygonaceae fruits (Menéndez, 1960), and leaves of Araucaria (Menéndez and Caccavari, 1966). More recently, Falaschi et al. (2012) studied the gymnosperms and pollen, and Caviglia and Zamaloa (2014) described a diverse assemblage of angiosperm leaves belonging to several families including Nothofagaceae, Myrtaceae, Rosaceae, Myricaceae, and Malvaceae among others, from the same Pico Quemado locality. Passalia and Bechis (2012) mentioned the presence of plant remains (including angiosperms, gymnosperms, and fern fronds) in an imprecisely located site at the Cordón Las Bayas hills.

\section{Material and methods}

The specimens described here were collected in two similar and about 10-15 m apart plant-bearing beds of reddish/orange to light brown tuffaceous wacke from the section measured at the Quebrada Vera site (Fig. 2). The fossils were studied with a binocular stereoscopic microscope Wild Heerbrugg and photographed with a Panasonic Lumix DMC-ZS20 (20 megapixels) digital camera. The material is housed at the Paleobotanical Collection of the Universidad Nacional del Sur, Argentina, under the acronym UNS PB 5289 to 5300 (even though some slabs may contain more than one plant remain they are only numbered with a single collection number). The systematic classification follows PPG I (2016) and Christenhusz et al. (2019). Terminology for the Equisetum description follows Hauke (1963). Fern frond morphotypes are named QV (Quebrada Vera abbreviation) followed by a number. Images of extant species were obtained from The Global Biodiversity Information Facility GBIF.org and the Cornell University Plant Anatomy Collection CU-PAC (http://cupac.bh.cornell.edu/), USA. 


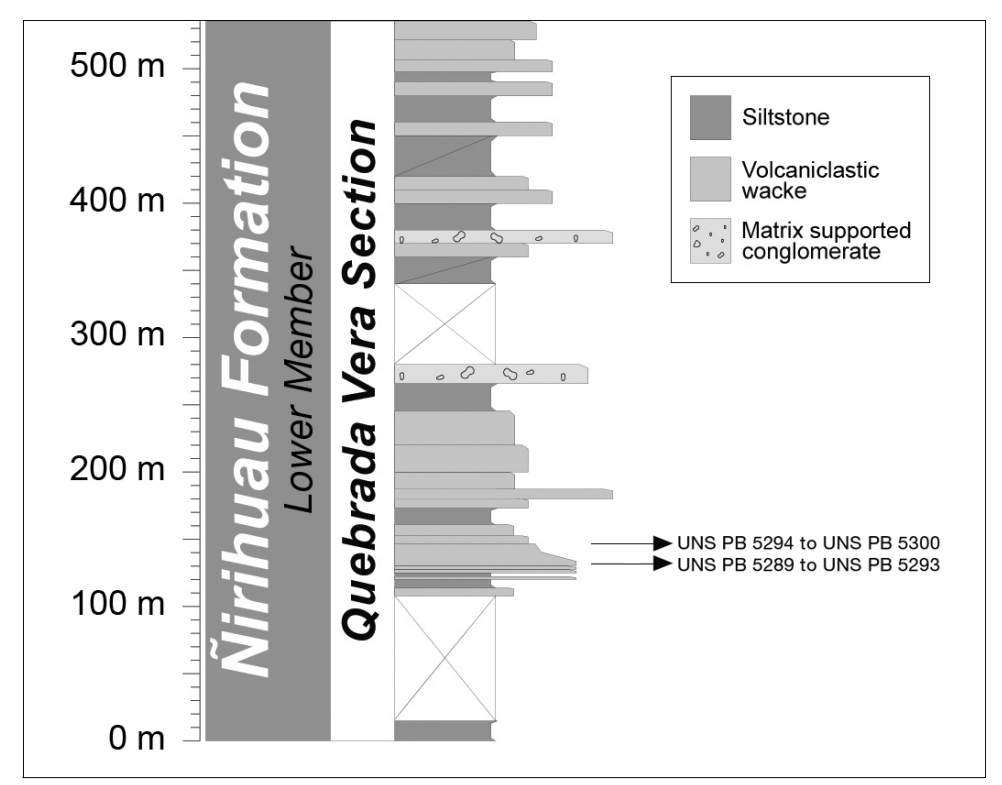

FIG. 2. Stratigraphic profile at the Quebrada Vera site, Miocene Nirihuau Formation, indicating the plant fossil bearing beds and sample locations.

\section{Systematic paleobotany}

Both collections exhibit similar taxonomic composition and therefore the assemblages are treated as a single paleoflora which consists of abundant impressions and molds of one species of horsetail (13 specimens) and several impressions of four different fern fronds ( 7 specimens). Fine morphological details (i.e., high order venation of the fronds, lateral branches scars or the nodal diaphragm structure) are preserved in several specimens.

Division Pteridophyta Schimper, 1879 Class Polypodiopsida Cronquist, Takht.\&W.Zimm., 1966 Order Equisetales de Candolle ex Bercht. \& Presl., 1820 Family Equisetaceae Michx. ex de Candolle, 1804 Genus Equisetum Linnaeus, 1753

Subgenus Hippochaete (Milde) Baker, 1887 Type species. Equisetum fluviatile L., 1753 (extant) Equisetum sp.

Fig. 3

Material. UNS PB 5292, 5293, 5297 (7 specimens), 5298 (2 specimens), 5299, and 5300.

Description. Fossils are fragments of jointed aerial stems, parallel-sided, that exhibit longitudinal ridges and furrows on their surface. Most internodes are incompletely preserved. Some of the specimens have an almost continuous ring of protruding scars at the node surface, and each scar consists of a longitudinally elliptical bulge which has a small central pit. The leaves are laterally fused at their bases forming a basal sheath that comprises about $65 \%$ of the total leaf length, while the apices remain free forming whorls of linear, acute, and adpressed teeth of 0.5-0.9 mm length. On the sheath, the leaves are laterally connected by narrow $(c a .0 .5 \mathrm{~mm})$ and parallel-sided commissural furrows. Small disperse fragments of shoots of 1.2-1.8 mm width with up to 8 furrows and whorls of free teeth are also present. The nodal diaphragms are flat, subcircular in outline, and with a faintly undulated margin; they have a large central spongy portion surrounded by a thin outer ring (1.8-2.5 mm width) delimited by numerous, definite, regularly disposed (0.6-0.7 mm apart), and rounded triangular traces. Measurements: minimum internode length $5 \mathrm{~mm}, 7 \mathrm{~mm}$ ( 2 specimens), stem width $10-40 \mathrm{~mm}$ (8 specimens), total number of ridges 32 to 54 ( 7 specimens), width of ridges 0.8-1.5 mm (5 specimens), width of furrows 0.09-0.45 $\mathrm{mm}$ (4 specimens), ratio of ridge number to stem width 1.4 (1.65) 2.0 (8 specimens). Scars at nodes $c a .2 \mathrm{~mm}$ length and $1 \mathrm{~mm}$ width, number of visible scars at nodes 12 ( 2 specimens). Nodal diaphragm maximum diameter $27 \mathrm{~mm}$ (2 specimens), triangular traces up to $0.6 \mathrm{~mm}$ height. 

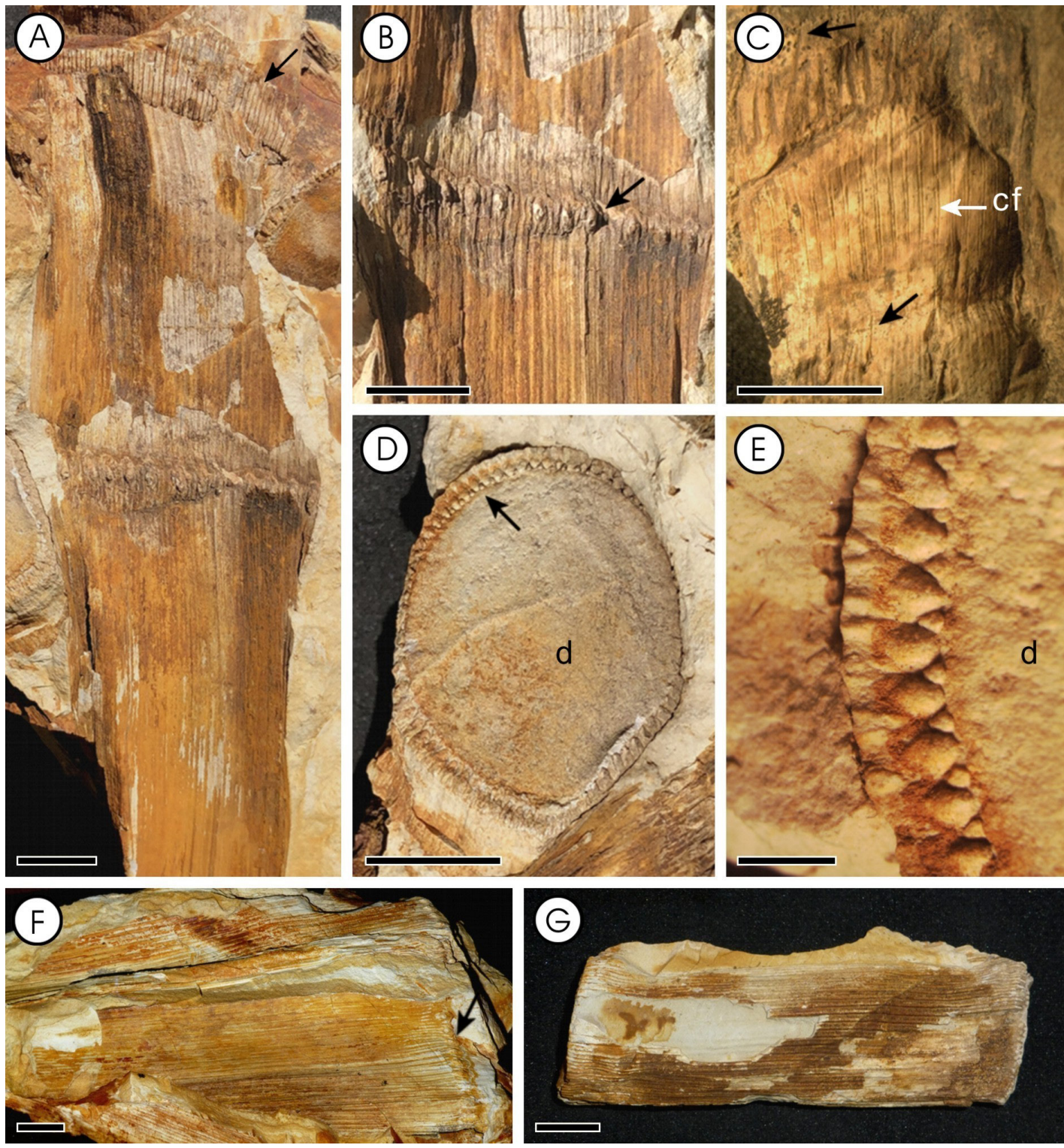

FIG. 3. Equisetum sp. from the Quebrada Vera site. A. (UNS PB 5297), aerial stem parallel-sided with longitudinal ridges and furrows and one node with elliptical scars. Note on the top remnants of a leaf sheath. B. Detail of the node in A. Note the elliptical scars and the central circular pit (arrow). C. (UNS PB 5298), detail of a short internode with a sheath of laterally fused leaves with free and acute apices (black arrows). Note commissural furrows (cf). D. (UNS PB 5297), nodal diaphragm (d) with a large pith and a thin outer ring with undulated margin (arrow). E. Detail of the peripheral ring in D. Note the numerous, regularly distributed, definite triangular traces. F. (UNS PB 5297), several stems. Note the scars at the node on the right side (arrow). G. (UNS PB 5299), mold of an internode. Bar= $1 \mathrm{~cm}$, except $\mathrm{E}$ bar $=2 \mathrm{~mm}$.

(Note. The total number of ridges was obtained by duplicating the number that is visible in the exposed half of the axis).

Geographic occurrence. Quebrada Vera, W Río Negro Province, Argentina.
Stratigraphic occurrence. Lower Member of the Ñirihuau Formation, Lower Miocene.

Comments. Several of the larger stem impressions and molds bear a ring of regularly arranged scars on the nodal surface (Fig. 3A, B). These marks are 
interpreted as the scars left by detached lateral branches because disperse small shoot impressions with similar diameters to those of the scars are found associated in the same plant-bearing beds. Additionally, each elliptical scar bears a circular central depression or pit that may correspond to the trace left by the pith of the lateral branch (Fig. 3B).

Leaf whorls are absent or partially preserved in branch-bearing nodes (Fig. 3A). In one specimen two leaf whorls delimiting an exceptionally short internode of about 2.2-3 cm are observed (Fig. 3C); this fragment may represent a subapical portion of the stem where internodes are still undergoing lengthening as can be seen in extant species (Fig. 4B). The commissural furrows run along the leaf sheath and they slightly widen distally (Fig. 3C). The leaf teeth are apparently stiff and always free (Fig. 3C).

The nodal diaphragm is characterized by a wide pith and a relatively narrow peripheral ring that is delimited inwardly by numerous small traces. Each

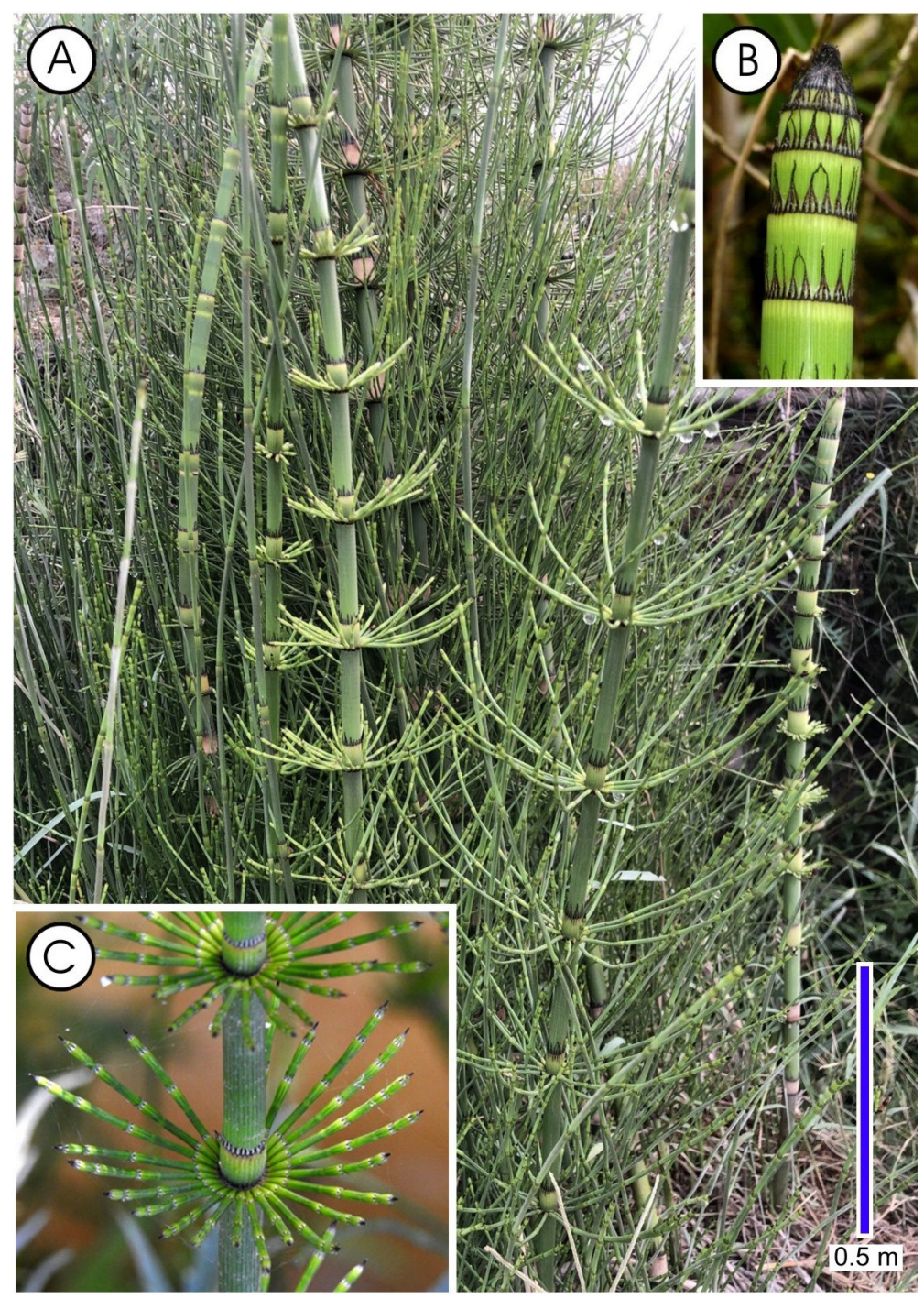

FIG. 4. Extant Equisetum giganteum. A. Aspect of a Peruvian stand dominated by giant horsetails. B. Apical portion of the aerial stem with short internodes. C. Stem node with radially arranged lateral branches. Images obtained from The Global Biodiversity Information Facility GBIF.org. A: https://www.inaturalist.org/photos/118101522. B: https://www.inaturalist.org/photos/111568028. C: https://www.inaturalist.org/photos/113636224. 
trace is aligned with a marginal ridge, so they are interpreted as evidence of the vascular bundles that run below the ridges and along the internodes as observed in extant species (Fig. 3D, E, Fig. 5). The marks alternate with rhombic bulges (up to $0.75 \mathrm{~mm}$ length) that are located below a surface furrow, in a position comparable to that occupied by the vallecular canals in extant species (Fig. 5). Towards the periphery each rhombic bulge is partially surrounded by a definite band (sometimes reddish in color) in which several cellular wall cavities can be recognized. This inner band may correspond to the inner cortex or chlorophyllous parenchyma of extant horsetails. The outer zone (outer cortex or sclerenchyma?) is compact and displays undulate surface relief that reaches the also undulate margin (Fig. 5).

Comparison with living species. The specimens exhibit a combination of morphological features that are characteristic of genus Equisetum, including the jointed axis ornamented with regularly spaced longitudinal internodal ridges, the leaf whorls basally fused and with free tips, and the nodal diaphragms with a definite peripheral ring.

Living horsetail species are herbaceous perennials and range in size from small plants that average a few centimeters tall to the "giant horsetails" that can reach heights of up to 8 meters (Hauke, 1963). According to the latest revised classification by Christenhusz et al. (2019), there are three extant giant Esquisetum species which have mainly a Central and South American distribution: E. giganteum L.
(Cuba, Jamaica, Haiti, Dominican Republic, Mexico, Guatemala, Costa Rica, Panama, Colombia, Venezuela, Ecuador, Peru, Bolivia, Paraguay, Uruguay, Brazil, Chile, and Argentina), E. myriochaetum Schltdl. \& Cham. (Mexico, Guatemala, El Salvador, Honduras, Costa Rica, Colombia, Ecuador, and Peru), and E. xylochaetum Mett. (Chile and Peru).

The aerial stem diameters of the Quebrada Vera specimens are close to the size of the largest living species E. giganteum and E. xylochaetum (Table 1), but the Patagonian fossil stems exhibit comparatively fewer ridges (number of ridges to width of stem ratio 1.5 versus 2.5 in E. giganteum and E. xylochaetum).

Additionally, Schaffner (1932) and more recently Christenhusz et al. (2019) noted that the two largest living species are morphologically and anatomically highly similar but the leaf sheaths display differences. While in E. giganteum the teeth are "membranous, friable and breaking off or imperfectly deciduous" they are rigid, linear, and often breaking off but leaving persistent bases in E. xylochaetum (Schaffner, 1932). The fossils are more similar to E. xylochaetum as they exhibit apparently rigid teeth (Fig. 3C) and persistent leaf sheath bases (Fig. 3A).

By analogy with extant species that can attain similar main stem diameters, a height close to $5 \mathrm{~m}$ can be estimated for some of the fossils and in such cases the relatively small diameters pose a challenge for stems mechanical stability as stated by Spatz et al. (1998) who analyzed the biomechanics of living E. giganteum. These authors concluded that isolated
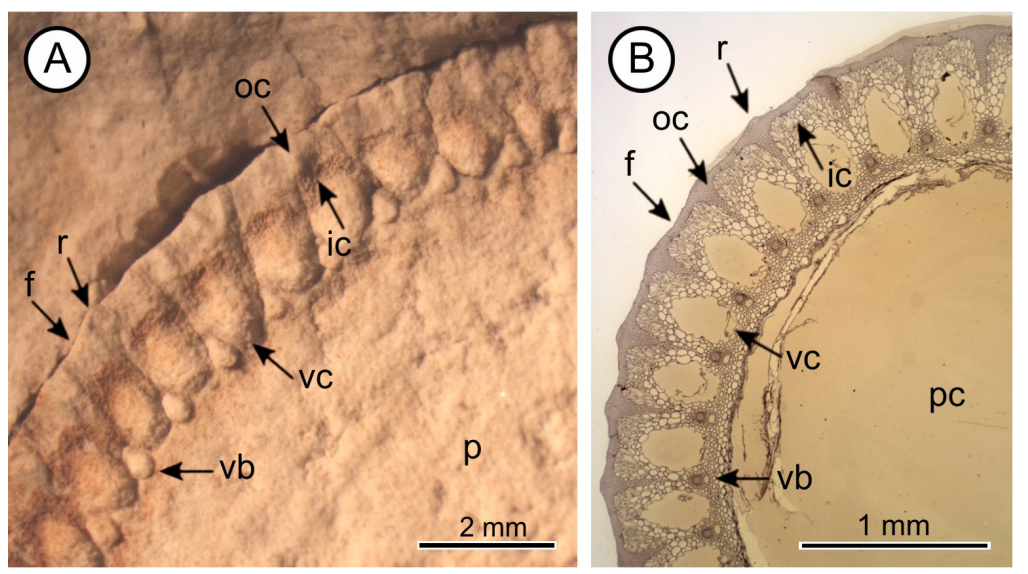

FIG. 5. Comparison between the fossil nodal diaphragm A (UNS PB 5297) and a cross section of stem of a living Equisetum B (CU-PAC image 8653). p: pith; pc: pith cavity; vb: vascular bundle; vc: vallecular canal; ic: inner cortex; oc: outer cortex; r: ridge; f: furrow. 


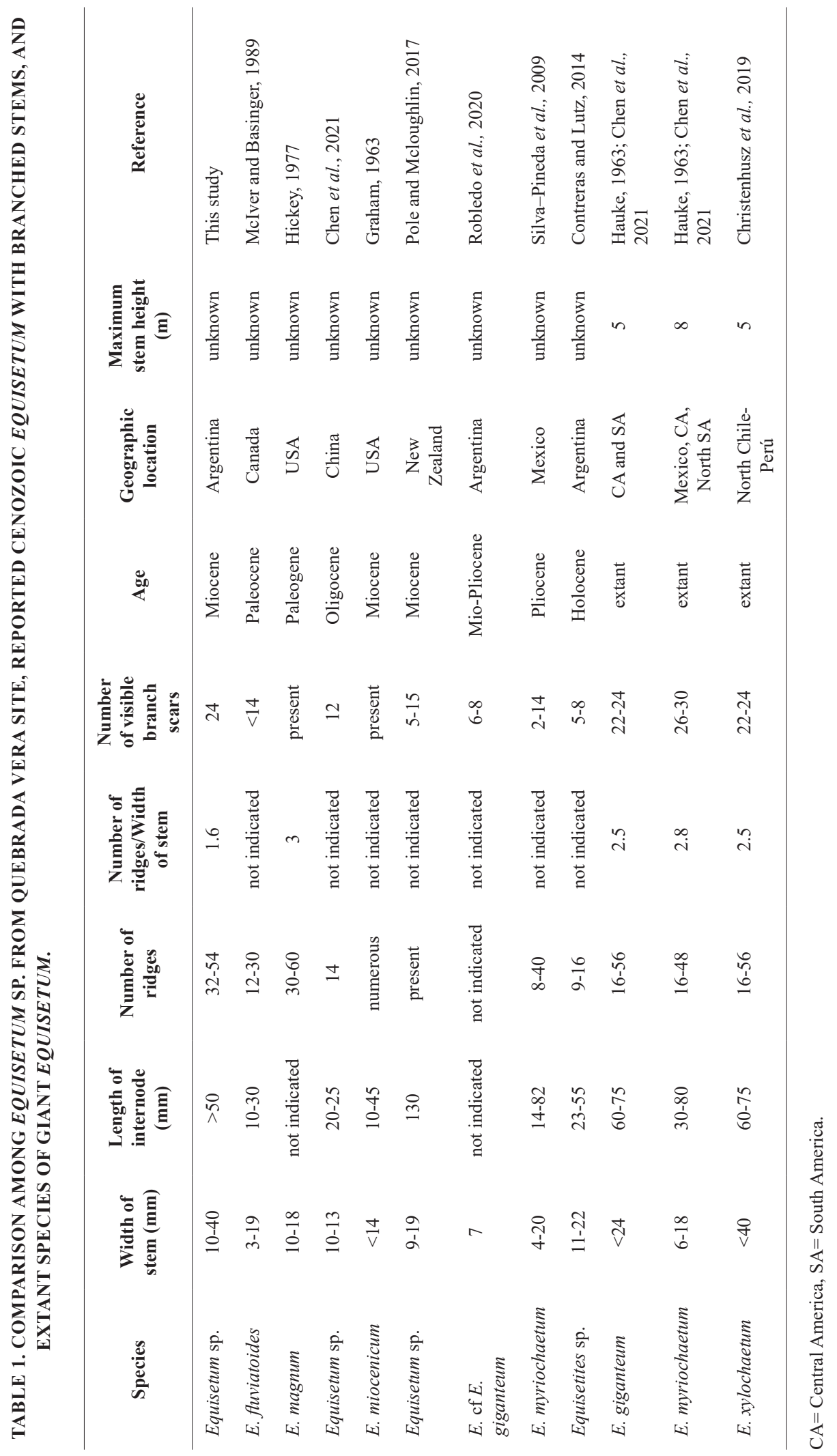


stems of more than $2.5 \mathrm{~m}$ height are mechanically unstable, but in dense stands individual stems support each other by interlacing with their lateral branches and so each stem can maintain an upright position (Fig. 4A, C). The fossils also possess numerous branch scars distributed in a radially symmetric pattern. This morphological feature, strongly linked to the mechanical stability of each individual stem, suggests that by the Miocene members of Equisetum had already attained the typical growth habit of their living relatives that provides mutual support to the plants.

The presence of stout stems along with the regular and radially branching pattern link the fossils with the extant giant horsetails which are included in Equisetum subgenus Hippochaete. Crucial information, related to epidermal characters and reproductive structures, is still missing and prevent further taxonomic allocation of the Quebrada Vera fossils.

Comparison with selected Cenozoic species. The Cenozoic record of Equisetum is especially abundant in the Northern Hemisphere, including North America, Europe, and Asia, and it is mostly represented by fragments of stems as well as numerous rhizomes and tubers. In contrast, Cenozoic horsetails are scarcely recorded in the Southern Hemisphere.

While reporting new findings of Equisetum from China, Chen et al. (2021) reviewed the past distribution of the genus and presented a comprehensive list of almost one hundred records ranging from Jurassic to Pliocene in age. Based on this compilation, six Cenozoic species, E. fluviatoides McIver and Basinger 1989, E. magnum Hickey 1977, E. miocenicum Graham 1963, E. myriochaetum, and two indeterminate species from New Zealand and China, exhibit lateral branches (or their scars) (Table 1). All these species differ from the Patagonian material in having slender stems that do not surpass $20 \mathrm{~mm}$ in width, and fewer branches or their scars.

Other horsetail records, that were not included in the list published by Chen et al. (2021), are impressions of a small and apparently unbranched stem fragment of Equisetum sp. (2-3 mm in diameter) with a spreading leaf sheath and a nodal diaphragm from Late Eocene or Oligocene sediments of Australia reported by Rozefelds et al. (2019) and an impression of an Equisetum sp. stem fragment of $6 \mathrm{~mm}$ wide with diffuse branch scars from the middle Miocene of Australia published by Holmes and Anderson (2019). The small stem size of these specimens along with diffuse or absent branch scars distinguishes them from the Patagonian ones.

In South America, Anzótegui and Horn (2011) recorded and illustrated one specimen of Equisetum sp. that consists of a jointed stem of $1.4 \mathrm{~cm}$ wide with toothed leaves from the Late Miocene of North Argentina. From the Holocene of the same region, Contreras and Lutz (2014) described Equisetites sp. represented by ribbed stem impressions of $11-22 \mathrm{~mm}$ in width with radial whorls of branches at the nodes that they found similar to E. giganteum. Robledo et al. (2020) reported Equisetum cf. E. giganteum from the Miocene-Pliocene also from Northern Argentina. This material consists of nodal diaphragms of up to $4.9 \mathrm{~mm}$ in diameter, branches and stem fragments of about $7 \mathrm{~mm}$ in average diameter, with 6 to 8 branch traces close to the nodes, and with about 20 triangular leaves (Table 1). The three known Cenozoic South American records come from northern Argentine deposits, and consist of stems and nodal diaphragms that are remarkably smaller than those of the Nirihuau Formation.

In sum, the Quebrada Vera Equisetum specimens are unique among all previously known Equisetum fossils for their large stems, and their consequently high number of lateral ramifications (indicated by the scars). This material represents the Cenozoic largest Equisetum so far known, and the first confirmed and most ancient record of a giant Equisetum registered worldwide. These Miocene fossils probably represent a new species within the giant Equisetum clade, nevertheless, further material with preserved diagnostic characters such as cuticular-stomatic and reproductive structures have yet to be discovered in order to establish a new species.

Evolutionary remarks. Several molecular-based phylogenetic studies of Equisetum have been carried out (e.g., Des Marais et al., 2003; Guillon, 2004, 2007; Christenhusz et al., 2019) providing different phylogenetic relationships and evolutionary scenarios. Des Marais et al. (2003) estimated that the Equisetum crown group probably diversified in the early Cenozoic whereas the Equisetaceae clade would have a Paleozoic origin. Likewise, these authors highlighted that their molecular analyses suggest that the ancestral condition for Equisetum was more likely a small, unbranched plant, while the large-sized and regular branching habit observed in the giant Equisetum would be a derived condition. These estimates were later 
supported by studies of Elgorriaga et al. (2018) and Christenhusz et al. (2021).

Elgorriaga et al. (2018) published a phylogenetic analysis of Equisetum combining molecular and morphological characters in which they included several fossil taxa. They estimated an early Cretaceous or even a Jurassic age for the origin of the Equisetum crown group, according to the ages proposed by Stanich et al. (2009). However, recently Christenhusz et al. (2021) based solely on molecular studies, estimated older dates than previously suggested and proposed that Equisetum diverged in the early Carboniferous and underwent a first major diversification during the middle Jurassic.

Furthermore, Des Marais et al. (2003) as well as Elgorriaga et al. (2018) plotted their respective phylogenetic trees against the geological timescale showing a post Pliocene maximum age for the origin of the giant Equisetum. On the contrary, Christenhusz et al. (2021, fig. 2) estimated an Eocene-Oligocene North American origin for the clade that includes the giant horsetails and proposed a dispersion route from North to South America during the Miocene (Christenhusz et al., 2021: 12) and an average age of 10.9 Ma for the origin of E. giganteum + E. xylochaetum clade (Christenhusz et al., 2021, fig. 2).

Remarkably, the results derived from the present study clearly demonstrate that the giant horsetails were established in the northern Patagonia communities at least by the early Miocene about $20 \mathrm{Ma}$. This age predates all the previously estimated ones by several million years.

Accompanying flora. Some fern frond impressions occur as minor components of the macroflora. These leaves are here described as morphotypes because they are morphologicaly similar to fronds found in several extant pteridophyte families such as Blechnaceae, Polypodiaceae, Pteridaceae, and Dryopteridaceae among others. Other diagnostic features that allow refining systematic assignments, such as those provided by cuticles and fertile organs, are not preserved.

\section{Order Polypodiales Link, 1833 Morphotype QV1 Fig. 6A}

Material. UNS PB 5292 (2 specimens).

Description. Fragments of pinnate fronds. Pinnae 6-11 $\mathrm{mm}$ in length and $1.5-2 \mathrm{~mm}$ in width, attached almost perpendicularly to the rachis, bases decurrent. Lamina narrow, parallel-sided, margin entire and rounded apices. Some pinnae apices steeply curved towards the top of the frond. Rachis and midveins prominent, secondary veins somehow obscure and emerging at acute angles. Proximal pinnae alternate, middle ones sub-opposite, and distal ones in opposite arrangement.

\section{Morphotype QV2 Fig. 6B, C}

Material. UNS PB 5290 and 5293.

Description. Fragments of tripinnate sterile fronds. Pinnae and pinnules alternate, margins parallel and entire, apices rounded, bases broadly attached to the rachilla and to the adjacent pinnule. Pinnule venation consisting of a decurrent midvein with numerous secondary veins free and once dichotomized. Lamina retrorse. Rachilla $c a$. $0.1 \mathrm{~mm}$ diameter; rachis $c a$. $1.5 \mathrm{~mm}$; pinnules $c a .2 .5 \mathrm{~mm}$ wide, and up to $7.5 \mathrm{~mm}$ long.

\section{Morphotype QV3 \\ Fig. 6D}

Material. UNS PB 5294.

Description. Fragment of bipinnate sterile frond. Pinnules elongate up to $9 \mathrm{~mm}$ length, 3-4 $\mathrm{mm}$ in width, alternately arranged, parallel-sided, bases broadly attached to the rachis (adnate), margins undulate to dentate, with one or two characteristic basal lobes irrigated by a prominent secondary basal vein. Midvein notorious, sunken and somehow arched. Secondary veins free and once forked. Rachis delicate and sunken.

\section{Morphotype QV4 Fig. 6E, $F$}

Material. UNS PB 5289 and 5291.

Description. Fragments of bipinnate sterile fronds. Pinnae alternate and perpendicularly attached to the raquis (Fig. 6F). Pinnae midvein (0.2-0.3 $\mathrm{mm}$ in width) straight in course. Pinnules opposite to sub-opposite, rarely alternate, lamina elongate triangular, cuneate or falcate, broadly attached to the axis at angles of $80^{\circ}-90^{\circ}$, with entire margins and rounded apices. The blades of adjacent pinnules are basally fused. Pinnule midvein (ca. $0.1 \mathrm{~mm}$ width) slightly decurrent and 

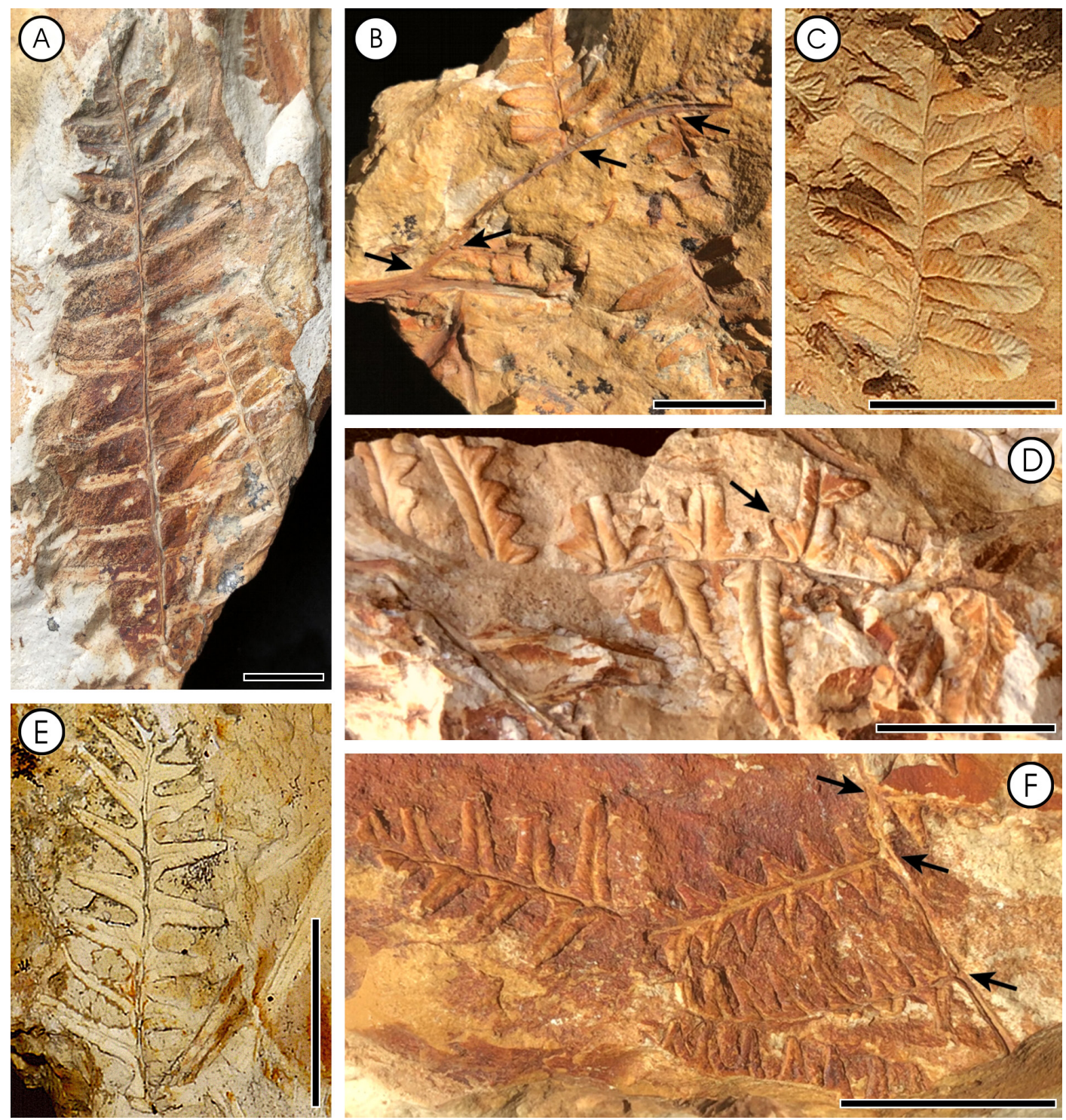

FIG. 6. Miocene fern fronds from Quebrada Vera site. A. Morphotype QV1(UNS PB 5292), pinnate fronds with reduced laminae. B-C. Morphotype QV2. B. (UNS PB 5290), bipinnate frond. Note the 2-order branching rachis (arrows). C. (UNS PB 5293), detail of the pinnules with rounded apices, robust and sunken midvein, and dichotomous secondary veins. D. Morphotype QV3 (UNS PB 5294), pinnate frond. Note the alternate arrangement of the pinnules and the basal lobes with prominent veins (arrow). E-F. Morphotype QV4. E. (UNS PB 5289), portion of a frond with rounded triangular pinnules broadly attached by their bases to a prominent rachis. F. (UNS PB 5291) portion of a frond with a 2-order branching rachis in alternate arrangement (arrows). Scale bars $=1 \mathrm{~cm}$.

thinning towards the apex. Secondary veins simple, numerous, and emerging at acute angles. Lamina retrorse. Rachis $0.2-0.4 \mathrm{~mm}$ diameter; pinnules 1.2-2.0 $\mathrm{mm}$ wide at the base and 2.3-4.0 $\mathrm{mm}$ long. Comments. The four fern leaves exhibit pinnae or pinnules with distinctive morphological features that allow easily differentiate them. Morphotype QV1 is the only apparently pinnate frond and has relatively large, elongate, and narrow pinnae. The unique tripinnate frond morphotype (QV2) has short, rounded and adnate pinnules. Morphotypes QV3 and QV4 represent bipinnate fronds that can 
be distinguished for the shape of the pinnules that are elongate and with basal lobules in QV3 and triangular to falcate in QV4.

\section{Discussion}

The floral assemblage recovered from the Quebrada Vera locality is entirely composed by pteridophytic elements. It is dominated by Equisetum accompanied by four fern leaf morphotypes. Such presence and dominance of giant horsetails make this fossil plant association quite interesting as it provides good indications on the past structure of the community and its environmental conditions. Furthermore, the good preservation of the material (i.e. the large size of most specimens, and pinnules attached to the frond rachises) suggests that the plants were buried near the growing site with minimum transport, indicating their autochthonous or para-autochthonous origin. Therefore, the paleoevironmental requirements inferred from the fossils are directly reflecting the local conditions at time of deposition.

Living horsetails are clonal plants characterized by an extensive underground rhizome from which aerial stems arise and, as a result of the abundant vegetative growth, extensive and dense stands can develop (Fig. 4A). When they grow tall, the lateral branches contribute to maintain the mechanical stability of the stems by interlacing with side branches of the neighbor plants. They are semiself-supporting plants that require mutual support or support of other vegetation (Spatz et al., 1998). Additionally, many horsetails are shade intolerant and poor competitors for light (Hauke, 1963) and occupy high vegetation strata. A similar landscape could have been present at the Quebrada Vera site, in which tall and dense Equisetum sp. stands developed above the lower and ground strata that were occupied by ferns.

Furthermore, because of their growth habit extant horsetails are early-successional plants that can rapidly invade barren areas if there is abundant groundwater supply. Thus, extant species usually grow in wet and sunny places, such as standing water of shallow ponds or ditches, along river and lake margins, marshes, or wet meadows (Hauke, 1978, 1990). Many ferns naturally grow in similar ecological conditions. The joint presence of horsetails and ferns in the fossil assemblage suggests that these plants might have grown close to a coastal riverside or lakeshore paleoenvironment. These paleowetland sceneries are consistent with those previously suggested for the Miocene Nirihuau Formation on sedimentary bases (Santonja et al., 2021 and references therein).

\section{Conclusions}

A Miocene flora collected at the Nirihuau Formation sediments exposed at the Quebrada Vera locality is recorded and described for the first time. The plant assemblage is composed exclusively of free-sporing plants, mainly giant Equisetum sp. accompanied by four types of leaf ferns.

By comparison with the ecological requirements of the living analogous of the paleoflora, it is estimated that the assemblage represents part of a littoral plant community growing in a wet environment (wetland), probably close to a riverside or lake margin, and that it was composed of a population of tall Equisetum sp. plants that occupied the upper stratum while several types of ferns developed in the lower community levels. Coincidently, previous sedimentary analyses estimate similar paleoenvironmental conditions for the depositional setting of the lower member of the Nirihuau Formation.

This is the first world's clear evidence of a fossil giant Equisetum so far known, which displays all morphological features of living largest Equisetum species (especially of the South American E. giganteum and E. xylochaetum). The presence of this putative new species in the Miocene of Patagonia demonstrates that the genus was established in southern latitudes in the Neogene in suitable paleoenvironments for its development. The age of these fossils implies that the date of origin of the giant horsetails must predate that estimated on molecular and combined morphological (living and fossil) and molecular data.

These new findings provide crucial information for understanding the past and present distribution range and history of Equisetum and are a perfect example on the importance of paleobotanical work when addressing biogeographical and evolutionary processes in deep time.

\section{Acknowledgements}

The authors thank to the Administración de Parques Nacionales of Argentina for allowing access to the study area, to the Instituto Geológico del Sur and Departmento 
de Geología, Universidad Nacional del Sur, Argentina. To Lic. M. Di Meglio and P. Balcells for their collaboration in making the figures. To M.A. Gandolfo (Cornell University, USA) for her valuable comments that greatly improved the manuscript. To J. Svitko (Cornell University, USA) for providing images of sections of Equisetum. To the reviewer A. Iglesias (Consejo Nacional de Investigaciones Científicas y Técnicas, Argentina) for the thorough reading of the manuscript and helpful suggestions.

\section{References}

Anzótegui, L.M.; Horn, Y. 2011. Megaflora de la Formación Palo Pintado (Mioceno Superior) Salta, Argentina. Parte II. Revista Brasileira de Paleontologia 14: 239-254.

Asensio, M.; Cornou, E.; Malumián, N.; Martínez, M.; Quattrocchio, M. 2010. Formación Río Foyel, Oligoceno de la cuenca de Nirihuau: la transgresión pacífica en la Cordillera Norpatagónica. Revista de la Asociación Geológica Argentina 66: 399-405.

Baker, J.G. 1887. Handbook of the fern-allies: a synopsis of the genera and species of the natural orders, Equisetaceae, Selaginellaceae, Lycopodiaceae, Rhizocarpeae. George Bell and Sons: 159 p. London.

Bechis, F.; Encinas, A.; Concheyro, A.; Litvak, V.D.; Aguirre-Urreta, B.; Ramos, V.A. 2014. New age constraints for the Cenozoic marine transgressions of northwestern Patagonia, Argentina $\left(41^{\circ}-43^{\circ} \mathrm{S}\right)$ : Paleogeographic and tectonic implications. Journal of South American Earth Sciences 52: 72-93.

von Berchtold, F.G.; Presl, J.S. 1820. O Prirozenosti Rostlin. Krala Wiljma Endersa: 322 p. Prague.

de Candolle, A.P. 1804. Essai sur les propriétés médicales des plantes, comparées avec leurs formes extérieures et leur classification naturelle. Didot Jeune: 148 p. Paris

Caviglia, N.; Zamaloa, M.C. 2014. Flora angiospérmica de Pico Quemado, Formación Ñirihuau (Oligoceno Tardío), Provincia de Río Negro, Argentina. Ameghiniana 51: 209-225.

Cazau, L.B. 1972. Cuenca de Nirihuau-Ñorquinco- Cushamen. In Geología Regional Argentina (Leanza, A.; editor). Academia Nacional de Ciencias de Córdoba: $727-$ 740. Córdoba.

Cazau, L.; Mancini, D.; Cangini, J.; Spalletti, L.1989. Cuenca de Nirihuau. In Cuencas Sedimentarias Argentinas (Chebli, G.; Spalletti, L.; editores). Serie Correlación Geológica 6: 299-318. Tucumán.

Channing, A.; Zamuner, A.; Edwards, D.; Guido, D. 2011. Equisetum thermale sp. nov. (Equisetales) from the
Jurassic San Agustín hot spring deposit, Patagonia: anatomy, paleoecology, and inferred paleoecophysiology. American Journal of Botany 98: 680-697.

Chen, H-Y; Yang, T.; Han, L.; Wang, Y.; Wang, H-J.; Bao, L.; Li, W-J.; Cai, J-H.; Liang, W-Y.; Dai, Y-Z.; Zhang, L.; Xie, S-P.; Yan, D-F. 2021. The Oligocene Equisetum from Qaidam Basin, Northeastern Tibetan Plateau in China and its implications. Historical Biology 33: 2845-2853. doi: 10.1080/08912963.2020.1830280.

Christenhusz, M.J.; Bangiolo, L.; Chase, M.W.; Fay, M.F.; Husby, C.; Witkus, M.; Viruel, J. 2019. Phylogenetics, classification and typification of extant horsetails (Equisetum, Equisetaceae). Botanical Journal of the Linnean Society 189: 311-352.

Christenhusz, M.J.; Chase, M.W.; Fay, M.F.; Hidalgo, O.; Leitch, I.J.; Pellicer, J.; Viruel, J. 2021. Biogeography and genome size evolution of the oldest extant vascular plant genus, Equisetum (Equisetaceae). Annals of Botany 127: 681-695.

Contreras, S.A.; Lutz, A.I. 2014. Primer registro de Equisetites sp. (Equisetaceae) en sedimentos cuaternarios del Río Bermejo (Formosa, Argentina). Boletín de la Sociedad Argentina de Botánica 49: 381-392.

Cronquist, A.; Takhtajan, A.; Zimmermann, W. 1966. On the higher taxa of Embryobionta. Taxon 15: 129-134.

Des Marais, D.L.; Smith, A.R.; Britton, D.M.; Pryer, K.M. 2003. Phylogenetic relationships and evolution of extant horsetails, Equisetum, based on chloroplast DNA sequence data ( $r b c \mathrm{~L}$ and trn LF). International Journal of Plant Sciences 164: 737-751.

Elgorriaga, A.; Escapa, I.H., Bomfleur, B.; Cúneo, R.; Ottone, E.G. 2015. Reconstruction and phylogenetic significance of a new Equisetum Linnaeus species from the Lower Jurassic of Cerro Bayo (Chubut Province, Argentina). Ameghiniana 52: 135-152.

Elgorriaga, A.; Escapa, I.H.; Rothwell, G.W.; Tomescu, A.M.; Cúneo, N.R. 2018. Origin of Equisetum: Evolution of horsetails (Equisetales) within the major euphyllophyte clade Sphenopsida. American Journal of Botany 105: 1286-1303.

Falaschi, P.; Zamuner, A.; Foix, N. 2009. Una nueva Equisetaceae fértil de la Formación La Matilde, Jurásico Medio, Argentina. Ameghiniana 46: 263-272.

Falaschi, P.; Zamaloa, M.C.; Caviglia, N.; Romero, E.J. 2012. Flora gimnospérmica de la Formación Ñirihuau (Oligoceno Tardío-Mioceno Temprano), Provincia de Río Negro, Argentina. Ameghiniana 49: 525-551.

Frenguelli, J. 1943. Proteáceas del Cenozoico de Patagonia. Notas del Museo de la Plata, Paleontología 8: 201-221. 
González Bonorino, F.; González Bonorino, G. 1978. Geología de la región de San Carlos de Bariloche. Revista de la Asociación Geológica Argentina 33: 175-210.

Graham, A. 1963. Systematic revision of the Sucker Creek and Trout Creek Miocene floras of Southeastern Oregon. American Journal of Botany 50: 921-936.

Guillon, J.M. 2004. Phylogeny of horsetails (Equisetum) based on the chloroplast rps4 gene and adjacent noncoding sequences. Systematic Botany 29: 251-259.

Guillon, J.M. 2007. Molecular phylogeny of horsetails (Equisetum) including chloroplast atpB sequences. Journal of Plant Research 120: 569-574.

Hauke, R.L. 1963. A taxonomic monograph of the genus Equisetum subgenus Hippochaete. Beihefte zur Nova Hedwigia 8: 1-123.

Hauke, R.L. 1978. A taxonomic monograph of Equisetum subgenus Equisetum. Nova Hedwigia 30: 385-455.

Hauke, R.L. 1990. Equisetaceae. In The Families and Genera of Vascular Plants (Kubitzki, K.; editor). I Pteridophytes and Gymnosperms (Kramer, K.U.; Green, P.S.; editors). Springer-Verlag: 46-48. Berlin.

Hickey, L.J. 1977. Stratigraphy and paleobotany of the Golden Valley Formation (Early Tertiary) of Western North Dakota. The Geological Society of America Memoir 150: 1-296.

Holmes, W.B.; Anderson, H.M. 2019. The Middle Miocene flora of the Chalk Mountain Formation, Warrumbungle Volcano Complex, NSW, Australia. Proceedings of the Linnean Society of New South Wales 141: S19-S32.

Link, H.F. 1833. Hortius Regius Botanicus Berolinensis. Tomus 2. APUD G. Reimer: 376 p. Berlin.

Linnaeus, C. von. 1753. Species plantarum, exhibentes plantasrite cognitas, ad genera relatas, cum differentiis specificis, nominibus trivialibus, synonymis selectis, locis natalibus, secundum systema sexuale digestas. L. Salvii, Holmiae: 1200 p.

McIver, E.E.; Basinger, J.F. 1989. The morphology and relationships of Equisetum fluviatoides sp. nov. from the Paleocene Ravenscrag Formation of Saskatchewan, Canada. Canadian Journal of Botany 67: 2937-2943.

Menéndez, C.A. 1960. Elementos florísticos del Terciario de Argentina. 1. Ruprechtia latipedunculata n. sp. del Arroyo Chenqueniyeu, Río Negro. Acta Geológica Lilloana 3: 15-19.

Menéndez, C.A.; Caccavari, M.A. 1966. Estructura epidérmica de Araucaria nathorsti Dusén del Terciario de Pico Quemado, Río Negro. Ameghiniana 4: 195-199.
Paredes, J.M.; Giacosa, R.E.; Heredia, N. 2009. Sedimentary evolution of Neogene continental deposits (Nirihuau Formation) along the Nirihuau River, North Patagonian Andes of Argentina. Journal of South American Earth Sciences 28: 74-88.

Passalia, M.G.; Bechis, F. 2012. Megafloras de la sección basal de la Formación Nirihuau (Oligoceno Superior?Mioceno Inferior) en las localidades Pico Quemado y Cordón de las Bayas, provincia de Río Negro, Argentina. In Simposio Argentino de Paleobotánica y Palinología No. 15. Proceedings in CD-ROM. Corrientes.

Pole, M.; McLoughlin, S. 2017. The first Cenozoic Equisetum from New Zealand. Geobios 50: 259-265.

PPG I (The Pteridophyte Phylogeny Group), 2016. A community-derived classification for extant lycophytes and ferns. Journal of Systematics and Evolution 54: 563-603.

Robledo, J.M.; Anzótegui, L.M.; Martínez, O.G.; Alonso, R.N. 2020. Flora and insect trace fossils from the Mio-Pliocene Quebrada del Toro locality (Gobernador Solá, Salta, Argentina). Journal of South American Earth Sciences 100: 102544.

Rozefelds, A.C.; Dettmann, M.E.; Milroy, A.K.; Hammond, A.; Clifford, H.T.; Ekins, M. 2019. The unexpected, recent history of horsetails in Australia. Australian Systematic Botany 32: 255-268.

Santonja, C.; Bechis, F.; Suriano, J.; Falco, J.I.; Encinas, A.; Olaizola, E.R.; Valencia, V.A.; Litvak, V.D.; Ramos, V.A. 2021. Tectono-stratigraphic evolution of the northeastern sector of the Nirihuau basin, North Patagonian Andes, Argentina: Insights from sedimentology and geochronology data of the Nirihuau Formation. Journal of South American Earth Sciences 111: 103487. doi: 10.1016/j.jsames.2021.103487.

Schaffner, J.H. 1930. Geographic distribution of the species of Equisetum in relation to their phylogeny. American Fern Journal 20: 89-106.

Schaffner, J.H. 1932. Diagnostic Key to the Species of Equisetum (Continued). American Fern Journal 22: 122-128.

Schimper, W.P. 1879. Palaeophytologie. In Handbuch der Palaeontologie 2 (1) (Zittel, K.A.; editor). R. Oldenbourg: 1-152. 117 figs. Munich and Leipzig.

Silva-Pineda, A.; Velasco de Leon, M.P.; Aguilar, F.J.; Chacon, E. 2009. An Upper Pliocene Equisetum (Equisetales) from the Atotonilco El Grande Formation in Central Mexico. Paleontological Journal 43: 216-225. 
Spalletti, L.A.1981. Facies sedimentarias de la Formación Ñirihuau en la región de San Carlos de Bariloche, provincia de Río Negro. Revista de la Asociación Geológica Argentina 36: 288-311.

Spatz, H-C.; Köhler, L.; Speck, T. 1998. Biomechanics and functional anatomy of hollow-stemmed sphenopsids. I. Equisetum giganteum (Equisetaceae). American Journal of Botany 85: 305-314.
Stanich, N.A.; Rothwell, G.W.; Stockey, R.A. 2009. Phylogenetic diversification of Equisetum (Equisetales) as inferred from Lower Cretaceous species in British Columbia, Canada. American Journal of Botany 96: 1289-1299.

Taylor, E.L.; Taylor, T.N.; Krings, M. 2009. Paleobotany: the biology and evolution of fossil plants. Academic Press: 1230 p. Cambridge.

Manuscript received: August 09, 2021; revised/accepted: November 24, 2021; available online: January 31, 2022. 